\title{
IMPLEMENTASI NETWORK ATTACHED STORAGE (NAS) MENGGUNAKAN FREENAS PADA STMIK LOMBOK
}

\author{
Lalu Supriadi Kalaena1, Wire Bagye², \\ 1,Teknik Informatika, STMIK Lombok \\ Jln. Basuki Rahmat No.105 Praya Lombok Tengah 83511 \\ ${ }^{1}$ supriadisadli162@gmail.com.2wirestmik@gmail.com,
}

\begin{abstract}
STMIK Lombok is an institution engaged in education that process data, about students, student practical data, lecturer data, and correspondence. Media file storage applied STMIK Lombok still on a separate computer, both academic data and practical data, so to access the file must be done on the computer where the storage. Based on the capability of Network Attached Storage in local network, by looking at the need of data storage media on the network at STMIK Lombok and the observation result then designed a network architecture by utilizing Network Attached Storage device with focus on fast storage and data transfer process. Stages of research include Data collection, design, and methods of testing To be able to help solve the problem of separate data access then implemented Network Attached Storage (NAS) which is a network to perform distribution of storage assets owned by the server of a network system that has the advantage of faster access to data stored through Local Area Network, minimal cost and cheap and easy maintenance, from setup to configuration, and available Open Source Software. After doing the testing phase it can be concluded that FreeNas as an operating system used for the processing of network storage media is very capable of handling the task well and the facilities that exist in it is very supportive in storage and accessing files. FreeNas web is very helpful and allows users to configure it other than it can be used without having to spend a large cost, and with the facilities in the FreeNas.
\end{abstract}

Keyword: FreeNAS, Local Area Network (LAN), Operating System (OS),

\begin{abstract}
Abstrak
STMIK Lombok merupakan institusi yang bergerak dibidang pendidikan yang mengolah data, mahasiswa, data praktikum mahasiswa, data dosen, dan surat menyurat. Media penyimpan file yang diterapkan STMIK Lombok masih pada komputer terpisah, baik data akademik maupun data praktikum, sehingga untuk mengakses file harus dilakukan pada computer tempat penyimpanan. Berdasarkan atas kemampuan dari Network Attached Storage dalam jaringan lokal, dengan melihat kebutuhan media penyimpanan data pada jaringan di STMIK Lombok dan hasil pengamatan maka dirancang sebuah arsitektur jaringan dengan memanfaatkan perangkat Network Attached Storage dengan menitikberatkan pada proses penyimpanan dan transfer data yang cepat. Tahapan penelitian meliputi Pengumpulan data, perancangan, dan metode pegujian Untuk dapat membantu mengatasi masalah akses data terpisah maka di implementasikan Network Attached Storage (NAS) yang merupakan suatu jaringan untuk melakukan distribusi asset storage yang dimiliki oleh server dari sebuah sistem jaringan yang memiliki kelebihan lebih cepat akses ke data yang tersimpan melalui Local Area Network, biaya minim dan perawatan yang murah dan mudah, mulai dari setup hingga konfigurasi, serta tersedia Software Open Source. Setelah dilakukan tahap pengujian maka dapat diambil simpulan bahwa FreeNas sebagai sebuah sistem operasi yang digunakan untuk pengolahan media penyimpanan jaringan sangat mampu menangani tugasnya dengan baik dan fasilitas-fasilitas yang ada didalamnya sangat mendukung dalam penyimpanan dan pengaksesan file. web FreeNas sangat membantu dan memudahkan User untuk mengkonfigurasinya selain itu bisa digunakan tanpa harus mengeluarkan biaya yang besar, dan dengan fasilitas yang ada di dalam FreeNas tersebut.
\end{abstract}

Kata Kunci: FreeNAS, Local Area Network (LAN), Sistem Oprasi (OS), 


\section{Pendahuluan}

Perkembangan penggunaan jaringan komputer pada beberapa instansi maupun perusahaan telah menjadi prioritas utama dalam pengolahan data. Hal ini terlihat dari adanya pemanfaatan perangkat server sebagai penyedia layanan basis data atau sering dikenal sebagai database server [5]

Media penyimpan file yang diterapkan STMIK Lombok masih pada komputer masingmasing, baik data civitasi akademik maupun data praktikum, sehingga kehilangan data yang disebabkan oleh virus ataupun kerusakan perangkat keras tidak dapat dihindari.

Network Attaced Storage merupakan sebuah server storage dengan sistem operasi yang salah satunya adalah FreeNAS yang dikhususkan untuk melayani kebutuhan data penyimpanan [5].FreeNAS dapat di akses langsung melalui jaringan lokal area dengan protokol TCP/IP dengan Keunggulan utama dari Network Attached Storage adalah proses transfer data yang cepat [2]. Berdasarkan atas kemampuan dari Network Attached Storage dalam jaringan lokal, dengan memanfaatkan perangkat Network Attached Storage yang menitikberatkan pada proses penyimpanan dan transfer data yang cepat. Untuk mengatasi masalah tersebut maka penulis membahas kajian tentang "Rancang Bangun Network Attached Storage (NAS) Menggunakan FreeNAS Pada LABKOM STMIK Lombok"

\section{Tinjuan Pustaka}

Farid Hidayat dari Universitas Narotama, Surabaya pada penelitian tentang Desain dan Implementasi Network Attached Storage Menggunakan FreeNas, berkembangnya penggunaan fasilitas teknologi informasi, maka informasi yang dapat disimpan akan semakin besar. Informasi-informasi yang disimpan dapat berupa email ataupun berupa data-data pada setiap perusahaan atau instansi, yang disimpan dalam sebuah database management system. Namun cara ini menghadapi beberapa kendala, salah satunya tidak scalable. Network Attached Storage (NAS) merupakan suatu jaringan untuk melakukan distribusi asset storage yang dimiiki server dari sebuah sistem jaringan. NAS memeliki beberapa keuntungan yaitu : Lebih cepat akses ke data yang tersimpan melalui Local Area Network, biaya minim dan perawatan yang murah dan mudah mulai dari setup hingga konfigurasi,
Tersedia Software Open Source. Network Attached Storage (NAS) dibangun di atas platform FreeNas. manfaat yang di peroleh adalah FreeNas sebagai sebuah sistem operasi yang digunakan untuk pengolahan media penyimpanan jaringan sangat mampu menangani tugasnya dengan baik dan fasilitas-fasilitas yang ada didalamnya sangat mendukung dalam penyimpanan dan pengaksesan file. Dengan adanya web FreeNas sangat membantu dan memudahkan user untuk mengkonfigurasi NAS.

Lekso Budi Handoko, Chaerul Umam, penelitian 2015 Teknik Informatika, Fakultas Ilmu Komputer, Universitas Dian Nuswantoro yang berjudul Analisa Efektifitas Penggunaan Network Resource Antara Storage Area Network (San) Dan Network Attached Storage (NAS) Server yang melayani sebuah fungsi akan menyimpan data yang dimilikinya pada media penyimpanan secara lokal di tiap server itu sendiri. Namun dengan semakin meningkatnya penggunaan, cara ini menghadapi beberapa permasalahan, yaitu tidak efisien, tidak scalable, dan tidak dapat dikelola dengan mudah. Oleh karena itu, perlu mempergunakan sistem media penyimpanan external terpusat bagi seluruh layanan. Tujuan dari paper hasil penelitian dan analisis ini adalah memberikan perbandingan konsep penyimpanan data terpusat dengan Storage Area Network (SAN) dan Network Attached Storage (NAS). Dimana yang dibandingkan adalah kecepatan baca dan tulis dari kedua konsep penyimpanan tersebut berkaitan dengan pemanfaatan network resource. Perbandingan ini akan memberikan referensi mengenai penyimpanan data terpusat mana yang paling efektif antara SAN dan NAS dalam menggunakan network resouce. Dari hasil penelian dapat di ambil kesimpulan, ternyata setelah dilakukan pengujian dapat dikatakan bahwa terdapat perbandingan antara kecepatan baca dan tulis SAN dan NAS. Oleh karena itu didapatkan SAN adalah yang paling efektif dalam memanfaatkan network resource dan efisien dalam proses baca dan tulis pada storage server.

Faishol shavalas c. r. yang berjudul Implementasi Network Attached Storage (Nas) Untuk Digital Library SMK Prakarya Internasional Bandung yang penelitiannya di SMK prakarya internasional bandung. SMK Prakarya Internasional Bandung memiliki sebuah perpustakaan konvensional, yaitu sebuah perpustakaan yang memiliki buku-buku yang diletakkan dalam rak-rak. Namun dengan seiring perkembangan zaman, referensi-referensi pendidikan mulai banyak yang berbentuk softfile. 
Selama ini, untuk membagi softfile tersebut ke para pelajar, selalu dengan menggunakan flashdisk. Hal ini sangat merepotkan karena jumlah siswa yang banyak. Untuk itu, muncul sebuah ide untuk membangun NAS sebagai media penyimpanan virtual yang bisa diakses melalui internet. NAS ini kemudian di integrasikan dengan sebuah website digital library. Proyek Akhir ini bertujuan untuk membangun NAS tersebut. NAS dibangun dengan OS FreeNAS yang di install pada salah satu komputer perpustakaan. Komputer server tersebut kemudian disambungkan dengan jaringan lokal SMK PI, sehingga FreeNAS tidak hanya bisa diakses diperpustakaan saja, namun juga bisa diakses di seluruh gedung.

Performansi NAS ditunjukkan melalui beberapa parameter, yaitu bandwidth, CPU Usage, System Load, serta jumlah maksimal user yang mampu ditampung dalam satu waktu. Hasil pengukuran yang telah dilakukan menunjukkan bahwa bandwidth bernilai antara 1 sampai 12 Mbit/sec, CPU Usage dengan rata-rata 1\%, System Load dengan rata-rata 0,06, serta simulasi jumlah maksimal user yang mampu ditampung oleh server menggunakan jmeter, dengan hasil maksimal 400 user dalam satu waktu.

\section{Metodologi Penelitian}

\subsection{Metode Pengumpulan Data}

1. Observasi

Mengadakan pengamatan secara langsung pada STMIK Lombok terkait model pengolahan dan penyimpanan data. Kapasitas perangkat keras dan server.

\section{Wawancara}

Melakukan tanya jawab kepada pegawai tentang bagaimana penyimpanan data dan akses.

\section{Studi Pustaka}

Mempelajari teori-teori baik dari buku-buku, jurnal dan internet yang berhubungan dengan tema penelitian.

\subsection{Metode Analisis}

Pada penelitian ini menggunakan metode analaisis PIECES.

\subsection{Metode Pengembangan}

Pengembangan menggunakan metode NDLC (Network Development Life Cycle)

\subsection{Metode Pengujian Sistem}

Peengujian dilakukan dengan melakukan upload dan download dari server FreeNAS ke klien yang menggunakan sistem operasi Windows 7

\section{Implementasi dan Hasil}

\section{Rancangan topologi dasar}

Rancangan topologi dasar yang dapat digunakan dapat digambarkan seperti gambar 4.1. berikut:

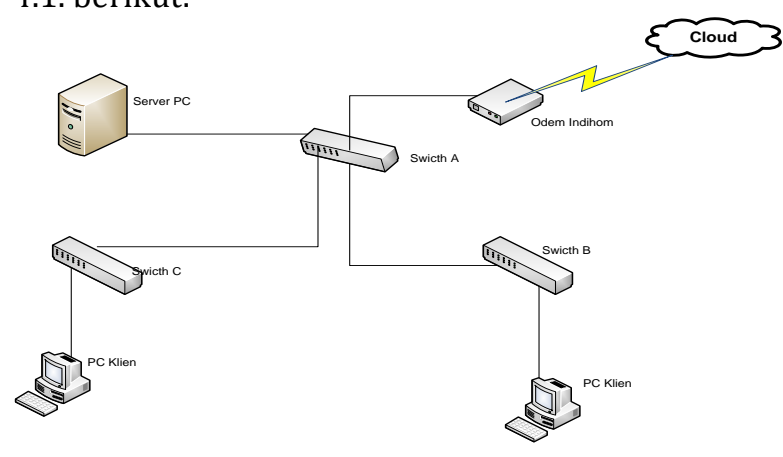

Gambar 4.1. Topologi dasar

Dari gambar di atas menunjukkan topologi yang digunakan untuk menghubungkan antara PC server dengan PC klien. Media menggunakan kabel UTP Cat. 5e yang mampu untuk menghubungkan. Rancangan pada gambar diatas Modem mendaoatkan IP dari ISP selanjutnya dari modem ke Swicth pertama yang terbagi ke3 acces point, PC server dan 2 swicth yang lansung dihubungkan kesemua klien.

\section{topologi Jaringan sebagai Network}

Attached Storage seperti gambar 4.2. berikut:

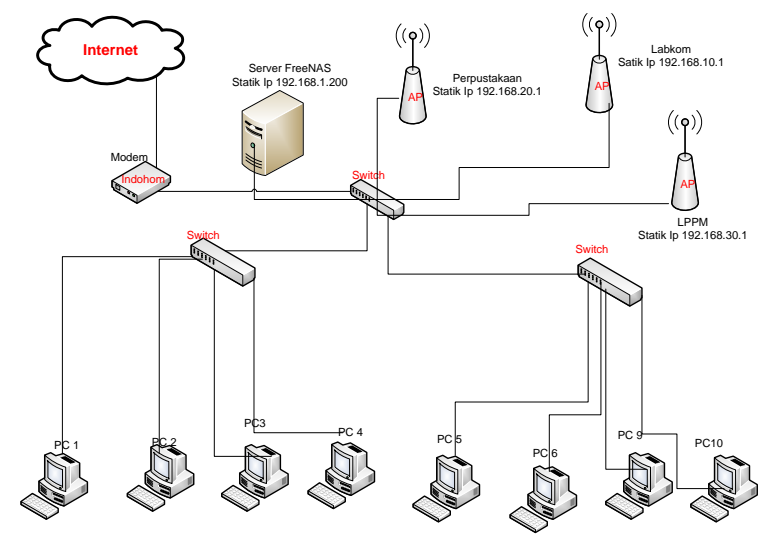

Gambar 4.2. Bentuk topologi Star

Dalam arsitektur sebelumnya Konfigurasi perangkat jaringan dari pada LABKOM 
menggunakan perangkat-perangkat seperti modem yang mendapatkan IP dari ISP yang diteruskan ke swictch serta access point pertama yang ada di ruang Labkom mendapatkan IP dan dikonfigurasi menjadi Statik denagan IP 192.168.10.1, sabnet Mask 255.255.255.0, begitu juga dengan akses point yang ada di Perpustakaan denagan IP 192.168.20.1 dan LPPM denagan IP 192.168.30.1, Akan tetapi dalam arsitektur yang di usulkan terjadi perubahan yaitu modem ke Switch pertama yang lansung terhubung ke access point yang ada diLabkom, Perpustakaan, dan LPPM dan juga terhubung lansung ke Switch yang ke2 dan ke3 serta PC server yang ada diruang Labkom, dari Switch yang ke2 dan ke3 terhubung lansung dengan PC klien dengan mendapatkan Ip DHCP menggunakan kabel UTP Cat5e dan konektor RJ45.

Perangkat lunak yang digunakan akan di tampilkan pada tabel 4.1

Tabel 4.1 Tabel Spesifikasi Software

\begin{tabular}{|l|l|l|}
\hline No & Software & Keterangan \\
\hline 1 & FreeNAS 9.10.1 & Sebagai sistem oprasi \\
\hline 2 & $\begin{array}{l}\text { Microsoft Office } \\
\text { Visio 2007 }\end{array}$ & $\begin{array}{l}\text { Untuk } \\
\text { menggambarkan } \\
\text { disain arsitektur }\end{array}$ \\
\hline 3 & $\begin{array}{l}\text { Windows 7 } \\
\text { Propesional }\end{array}$ & Untuk klien \\
\hline
\end{tabular}

Spesifikai Hardware yang digunakan untuk konfigurasi Server Network Atached Strong

Tabel 4.2 Tabel Spesifikasi kebutuhan perangkat keras

\begin{tabular}{|c|c|c|c|}
\hline No & Perangkat & Satuan & Spesifikasi Unit \\
\hline 1 & Server & 1 & $\begin{array}{l}\text { CPU: AMD A6-5400K. Trinity } \\
\text { Dual Core 3.6ghz Soket FM2 } \\
\text { APU With Directx } 11 \text { Graphic } \\
\text { AMD RadeonHD 7540D, } \\
\text { MEMORY: } 4 \text { GB DDR3. } \\
\text { HARDDIK }\end{array}$ \\
\hline 2 & Modem & 1 & 4 Gigabit Ethernet, 2 Pots, Wifi \\
\hline 3 & PC KlienA & 15 & $\begin{array}{l}\text { CPU : Intel @ Core(TM)2Duo } \\
\text { CPU E6550 @ 2.33ghz } \\
\text { Memory (RAM): } 512 \text { MB (502 } \\
\text { MB Usable) }\end{array}$ \\
\hline 4 & PC KlienB & 2 & $\begin{array}{l}\text { CPU : Intel @ Core(TM)2Duo } \\
\text { CPU E6550 @ 2.33ghz }\end{array}$ \\
\hline 5 & Switch A & 1 & $\begin{array}{l}\text { Standards And Protocols : } \\
\text { (IEEE 802.3, 802.3u, 802.3af) } \\
\text { (CSMA/CD, TCP/IP) }\end{array}$ \\
\hline 6 & Switch B & 1 & $\begin{array}{l}\text { Standards And Protocols : } \\
\text { (IEEE } 802.3,802.3 \mathrm{u}, 802.3 \mathrm{af} \text { ) } \\
\text { (CSMA/CD, TCP/IP) }\end{array}$ \\
\hline 7 & $\begin{array}{l}\text { Switch } \\
\text { (Hub)C }\end{array}$ & 1 & Port : $16-10 / 100 \mathrm{Mbps}$ \\
\hline 8 & Kabel UTP & 30 & $\begin{array}{l}\text { UTP Cable Type : CAT 5e High } \\
\text { Quality (HQ) Connection } \\
\text { Applicable }\end{array}$ \\
\hline
\end{tabular}

\section{Uji Coba Jaringan}

Uji coba jaringan dilakukan dengan melakukan pengujian koneksi dari klien ke server dan dari server ke klien. Hasil pengujian seperti yang ditunjukkan pada gambar 4.3 dengan ping menunjukkan respon yang baik antar kedua pihak.

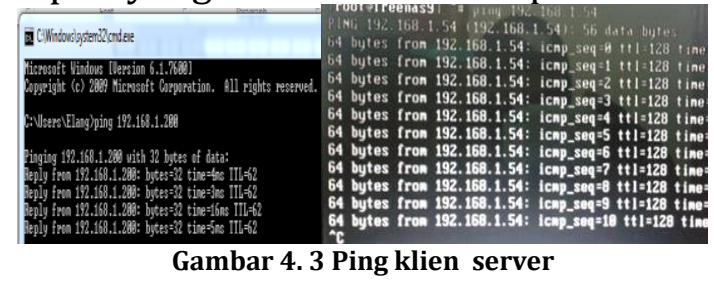

Setiap media fisik yang ada di FreeNAS harus digabungkan ke Volume Group atau dibuat menjadi media logikal. Ada 2 pilihan yang harus dilakukan dalam pembuatan Volume Group yaitu stripe (menganggap semua harddisk sebagai 1 media dan data akan disebarkan ke seluruh harddisk dan mirror (sebuah harddisk akan berfungsi sebagai cermin atau kloning dari harddisk lainnya).

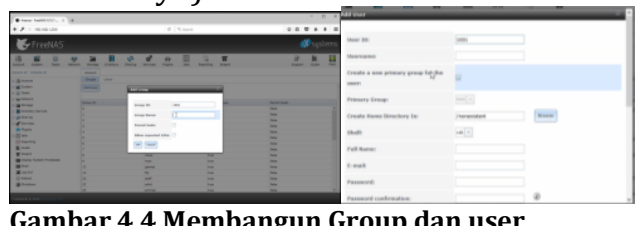

\section{Kesimpulan dan saran}

Kesimpulan merupakan pernyataan singkat, jelas, dan tepat tentang apa yang diperoleh, memuat keunggulan dan kelemahan, dapat dibuktikan, serta terkait langsung dengan tujuan penelitian. Uraian pada bagian ini harus merupakan pernyataan yang pernah dianalisis/dibahas pada bagian sebelumnya, bukan pernyataan yang sama sekali baru dan tidak pernah dibahas pada bagian sebelumnya, serta merupakan jawaban atas permasalahan yang dirumuskan. Bagian ini tidak perlu ada uraian penjelasan lagi.

Saran memuat berbagai usulan atau pendapat yang sebaiknya dikaitkan oleh penelitian sejenis. Saran dibuat berdasarkan kelemahan, pengalaman, kesulitan, kesalahan, temuan baru yang belum diteliti dan berbagai kemungkinan arah penelitian selanjutnya 


\section{Daftar Pustaka:}

Azikin, Askari. 2011. Debian GNU/LINUX. Informatika. Bandung.

Faishol shavalas c. r.berjudul Implementasi Network Attached Storage (Nas) Untuk Digital Library SMK Prakarya Internasional Bandung.

Hariyanto, Bambang. 2009. Sistem Informasi. Informatika. Bandung

Herlambang, Moch. Linto dan Azis Catur L. 2008. Panduan Lengkap Menguasai Router Masa Depan Menggunakan Mikrotik RouterOS. Yogyakarta. CV. Andi Offset.

Lekso Budi Handoko, Chaerul Umam. 2015 Teknik Informatika. Universitas Dian Nuswantoro yang berjudul Analisa Efektifitas Penggunaan Network Resource Antara Storage Area Network (San) Dan Network Attached Storage (NAS)

Lombok, S. T. M. I. K., and Ahmad Susan Pardiansyah. "Audit Tata Kelola Teknologi Informasi Program Studi Sistem Informasi Sekolah Tinggi Manajemen Informatika Dan Komputer (STMIK) Lombok Menggunakan." IJSE-Indonesian Journal on Software Engineering 1.1 (2015).
Sopandi, Dede. 2006. Instalasi dan Konfigurasi Jaringan Komputer. Bandung. Informatika.

Suarna, Nana. 2007 Pengantar (LAN) Local Area Network. Bandung: Yrama Widya

Tiphon. "Telekomunikations and Internet Protokol Haminization Over Network (TIPHON) Gineral Aspects F Quality Of Service (Qos)", DTR/TIPHON-05006(eb001cs.PDF)19

Lombok, Hairul Fahmi-STMIK. "Efektifitas Wireless Lan Berbasis 802.11 b/g Sebagai Solusi Jaringan Kampus (Studi Kasus: Sekolah Tinggi Agama Hindu (STAHN) Gde Pudja Mataram." IJNS-Indonesian Journal on Networking and Security 4.4 (2015).

Khairul Imtihan. "Perencanaan Strategi Sistem Informasi Pendidikan Pada Sekolah Tinggi Manajemen Informatika dan Komputer (STMIK) Lombok." Bianglala Informatika 3.2 (2015)

Hodia, Maelani, and Khairul Imtihan-STMIK Lombok. "Perancangan Sistem Informasi Praktek Klinik Kebidanan (PKK) Pada Prodi DIII Kebidanan Stikes Qamarul Huda." IJNS-Indonesian Journal on Networking and Security 6.3 (2017). 